\title{
Production of Herbal Mixes (Jamulacang) Instant as an Effort to Increase Immune to Prevent Covid 19
}

\author{
Any Sutiadiningsih ${ }^{1, *}$ Niken Purwidiani ${ }^{1}$, Agung Prijo Budijono ${ }^{1}$, Yunus ${ }^{1}$, Veni \\ Indrawati $^{1}$, Meda Wahini ${ }^{1}$ \\ ${ }^{1}$ Department of Family Welfare Education, Universitas Negeri Surabaya, Surabaya, Indonesia \\ *Corresponding author. Email: anysutiadiningsih@unesa.ac.id
}

\begin{abstract}
This program of activities was carried out in an effort to help prevent the spread of the epidemic and prevent the transmission of the Covid-19 virus. This prevention effort was carried out by the PKM implementation team by making instant herbal mix herbs made from raw ginger, ginger, secang, cardamom, nutmeg flowers and sugar, named "JAMULACANG INSTAN". Production jamulacang instan is one of the alternative solutions offered by the PKM Implementation Team to improve the body's immune system because the jamulacang instan material has good benefits as an antioxidant that can counteract free radicals that destroy body cells, while increasing endurance. By consuming instant jamulacang routinely, it is hoped that it can increase the body's immune system that is able to resist attacks and be able to prevent covid transmission 19. From the implementation of PKM activities, 500 packs of "JAMULACANG INSTAN" have been produced in 120 grams / pack and have been submitted at LPPM Unesa.
\end{abstract}

Keywords: Herbal Mixes, Jamulacang, Immune, Covid-19

\section{INTRODUCTION}

Coronavirus disease (COVID-19) is an infectious disease caused by a new type of virus that has never been identified in humans. People with COVID-19 can experience fever, dry cough and difficulty breathing. Sore throat, runny nose, or sneezing are less common. According to the Government Spokesperson for Coronavirus Treatment Achmad Yurianto announced that until April 27, 2020, the total number of corona cases in the country was 9,096 people, the number of patients recovered was 1,107 people and patients died from this disease reaching 748 people. The spread of the Covid-19 epidemic has made the government and all levels of academia take various ways to stem the spread of the virus, one of which is through increasing the body's immune system by consuming herbal herbal concoctions [2].

Jamu is a mixture of plants, animals, pelicans and minerals which have medicinal properties. The main difference between modern medicine and traditional medicine is that traditional medicine in its manufacture does not require chemicals, usually only requires cold water or hot water for brewing. So the nutritious substances do not need to be separated first, even what substances are effective is not necessarily known with certainty. In addition, traditional medicine has a much more complex structure than modern medicine, so that studying its chemical composition is more complicated [3].

The concoction of ginger, turmeric, and ginger is one of the herbal recipes that can be consumed regularly. These three ingredients have good antioxidant benefits which can ward off free radicals that destroy body cells, while increasing endurance. Temulawak is a plant that is believed to provide protective benefits for the liver, while ginger improves blood circulation and warms the body. Turmeric is a natural antibiotic that can also protect digestion. Turmeric or Curcuma longa has the main active compound of curcumin which has anti-inflammatory, analgesic, and immunomodulatory activities. In addition, turmeric also contains unique active substances, namely curcuminoide and ukanon types A, B, C, and D which function to stimulate the body's resistance. Cinnamon is rich in antioxidants, even being one of the spices with the highest antioxidant content. These antioxidants can protect the body from several diseases, such as flu. Gotu Kola (Centela asiatica) is a traditional plant that has benefits as an immunomodulator in diseases that require cellular and humoral immune system defense. The content of triterpenoid glycosides and asiaticoside compounds accelerates the repair of skin cells and increases non-specific resistance [1]. 
The Covid-19 pandemic in Indonesia has a multi-sectoral impact, from health, education, social, economy to society. The public is starting to feel the impact on these sectors. This concerns the issue of social welfare in society. The spread of the Covid-19 outbreak has made the government and all levels of academics take various ways to stem the spread of the virus. Therefore, it is necessary to take concrete steps in overcoming these problems

\section{METHOD}

The method used to make or produce Instant Herbal Mixes made from ginger, temu lawak, nutmeg, secang and other herbal ingredients called Jamulacang as an effort to increase body immunity, is carried out for 3 months according to the provisions set by the University are as follows:

a. Identify the ingredients of the spices that will be used for the manufacture and production of Instant herbal mix (Jamulacang).

b. Determining the method of activity, namely making jamulacang spices consisting of the following stages: material preparation, production process, packaging and distribution of herbal medicine.

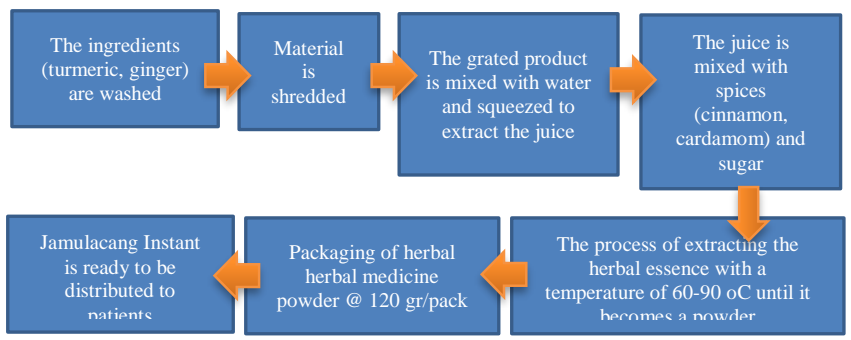

Figure 1 Making process of jamulacang herbal instan

\section{RESULT AND DISCUSSION}

The PKM program activities for PNPB Unesa funds are carried out in an effort to assist and support government programs in preventing the transmission of the Covid-19 virus. to communities in some districts/cities in East Java, such as the City of Surabaya and Jombang Regency to help prevent the transmission and spread of Covid-19. The main product produced by the Implementation Team of the Unesa PNPB PKM program activities is entitled Making Instant Herbal Mix (Jamulacang) as Immune Enhancement Efforts to Prevent Covid 19 are Instant Herbal Mix Herbs made from empon-empon and spices, such as ginger, temu lawak, nutmeg, secang and other herbal ingredients called "JAMULACANG INSTAN". Jamulacang Instant which is produced from raw materials for empon-empon, if consumed regularly, can increase the body's immunity, so that the body is able to prevent transmission and fight against the covid 19 virus.

The steps in the production process of the "INSTANT JAMULACANG" herbal mix are: (1) Washing the emponempon ingredients, such as ginger, turmeric, and ginger, (2)
Grate the empon-empon ingredients, such as ginger, turmeric and ginger , (3) Press the shredded empon-empon to extract the juice, (4) Mix the extract of the empon-empon extract with spices (cinnamon, cardamom) and sugar, (5) Ekatrasi the herbal essence with a temperature of $60-90^{\circ} \mathrm{C}$ until formed, (6) Pack the herbal mix powder "Jamulacang Instant" in packs of $120 \mathrm{gr} / \mathrm{pack}$, (7) Distribute Jamulacamg Instant to the public.

The activity of the "Instant Jamulacang" production process by the PKM program implementation team can be seen in the photo of the following activity:

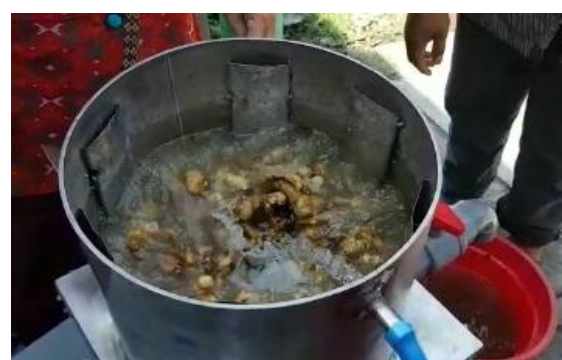

Figure 2 The process of washing and stripping the emponempon

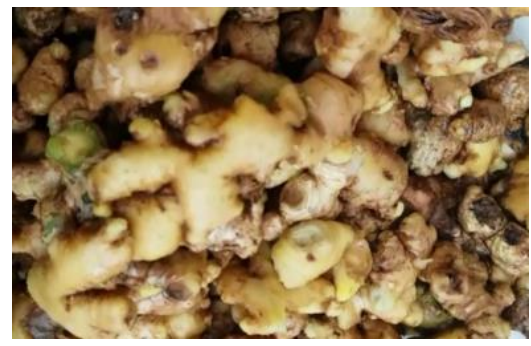

Figure 3 Empon-empon that has been cleaned

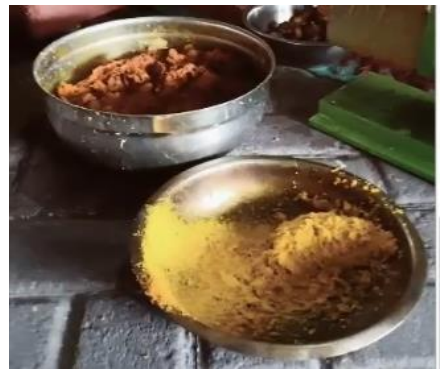

Figure 4 Result of grater empon-empon

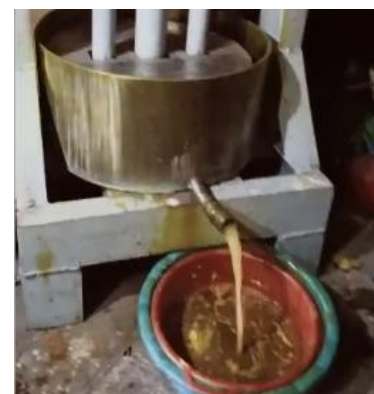

Figure 5 Pressing/squeezing the empon-empon (Ginger) 


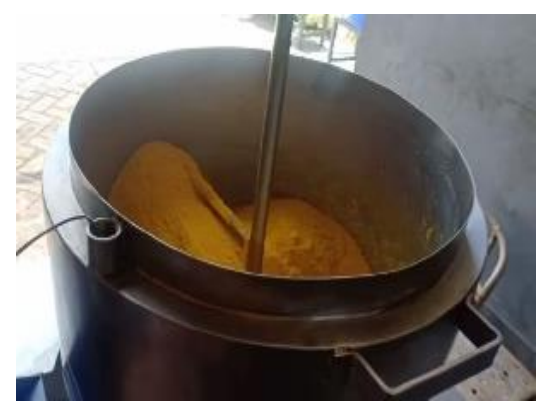

Figure 6 Extraction Process "JAMULACANG INSTAN"

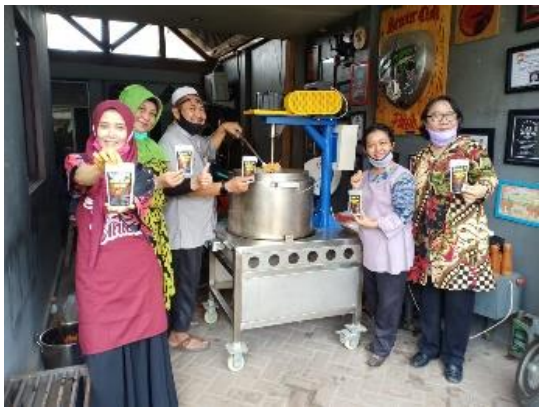

Figure 7 JAMULACANG INSTAN completed in production

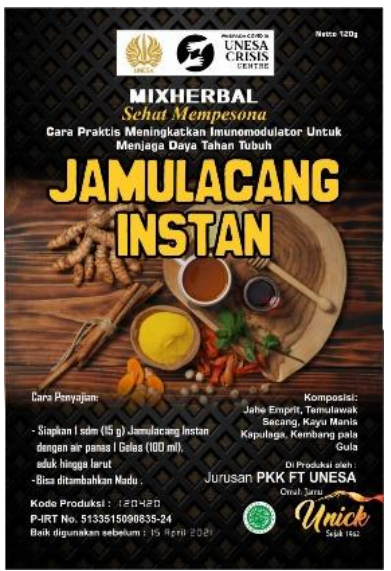

Figure 8 Wrap Packaging "JAMULACANG INSTAN

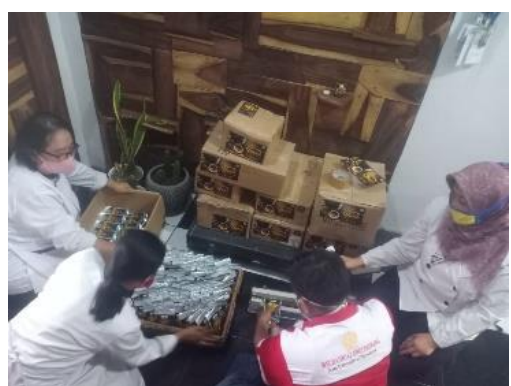

Figure 9 Packaging Process

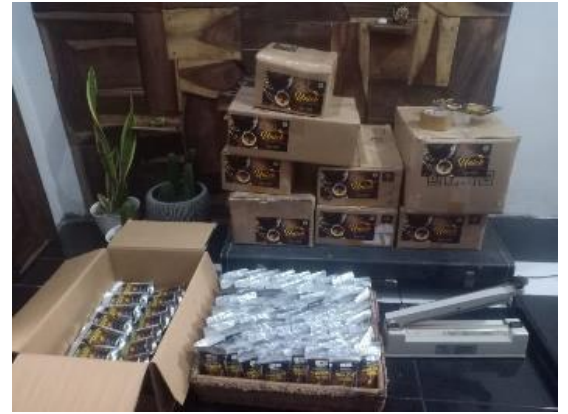

Figure 10 JAMULACANG INSTAN Finish Packed

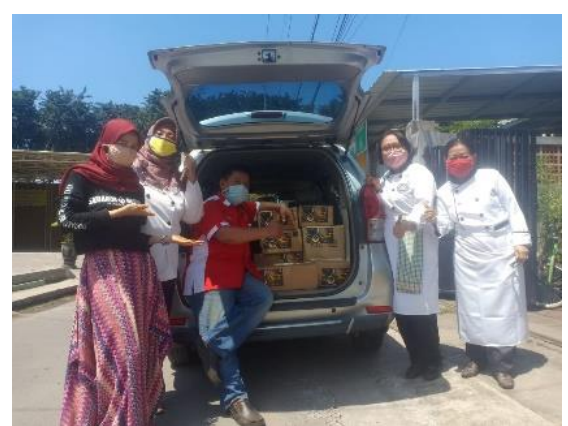

Figure 11 Delivery JAMULACANG INSTAN to LPPM Unesa

\section{CONCLUSION}

The implementation of this program has gone well. The main product produced from this PKM activity is herbal mix herbs made from raw materials for empon-empon and spices, namely ginger, temu lawak, nutmeg, secang and other herbal ingredients called "JAMULACANG INSTAN". Jamulacang Instant which is produced from raw materials for emponempon, if consumed regularly, can increase the body's immunity, so that the body is able to prevent transmission and attack the covid 19 virus. The implementation team of the activity has succeeded in producing 500 packs of Jamulacang Instant and has been submitted to LPPM Unesa.

The steps in the production process of the "INSTANT JAMULACANG" herbal mix are: (1) Washing the emponempon ingredients, such as ginger, turmeric, and ginger, (2) Grate the empon-empon ingredients, such as ginger, turmeric and ginger , (3) Press the shredded empon-empon to extract the juice, (4) Mix the extract of the empon-empon extract with spices (cinnamon, cardamom) and sugar, (5) Ekatrasi the herbal essence with a temperature of $60^{\circ}-90^{\circ} \mathrm{C}$ until formed, (6) Pack the herbal mix powder "Jamulacang Instant" in packs of $120 \mathrm{gr} / \mathrm{pack}$, (7) Distribute Instant Jamulacamg to the public.

\section{REFERENCES}

[1] Adhi, Irawan Sapto, 2020. 8 Manfaat Temulawak Selain Meningkatkan Daya Tahan Tubuh. Dikutip pada tanggal 28 April 2020 dari:

https://health.kompas.com/read/2020/04/19/055900168/8manfaat-temulawak-selain-meningkatkan-daya-tahan-tubuh 
[2] Debora, Yantina. 2020. Bahaya Virus Corona Covid-19 dan Cara Mencegahnya. Dikutip pada tanggal 29 April 2020 dari: https://tirto.id/bahaya-virus-corona-covid-19-dancara-mencegahnya-eKdF.
[3] Depkes RI. 1995. Materia Medika Indonesia Jilid VI.

Dirjen Pengawasan Obat dan Makanan Depkes RI. Jakarta. 